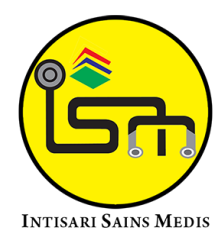

Published by Intisari Sains Medis

\section{Mikrobiota usus pada dermatitis atopik}

\author{
Dewi Gotama ${ }^{1 *}$, Made Wardhana ${ }^{2}$, Adeline Santoso ${ }^{1}$, Sissy $^{1}$
}

'Residen Departemen Dermatologi dan Venereologi, Fakultas Kedokteran Universitas Udayana/RSUP Sanglah;

${ }^{2}$ Departemen Dermatologi dan Venereologi, Fakultas Kedokteran Universitas Udayana/RSUP Sanglah;

\section{*Korespondensi:}

Dewi Gotama;

Residen Departemen Dermatologi dan Venereologi, Fakultas Kedokteran Universitas Udayana/RSUP Sanglah;

dewi_gotama@yahoo.com

Diterima: 07-03-2021

Disetujui: 10-08-2021

Diterbitkan: 31-08-2021

\section{ABSTRACT}

Atopic dermatitis (AD) is a multifactorial disease caused by immune dysregulation, genetic susceptibility, environmental factors, and impaired barrier function. The health burden caused by this disease is significant and can impact psychological, social and financial costs, along with systemic comorbidities. Several studies have reported the gut microbiota in $A D$ patients. Several studies have reported the gut microbiota in $A D$ patients. The gut microbiota is thought to play an important role in the development of $A D$ by regulating

the immune system's maturation. Intestinal microbiota alteration affects the balance of the immune system through metabolites' production, which will cause the microenvironment to become inflamed. Currently, the close relationship between the gut microbiota and the development of the immune system, especially in maintaining the balance of Th- 1 and Th-2 responses, is the rationale for providing probiotic supplements to prevent or treat allergic and atopic diseases.

Keywords: atopic dermatitis, intestinal microbiota, probiotic.

Cite This Article: Gotama, D., Wardhana, M., Santoso, A., Sissy. 2021. Mikrobiota usus pada dermatitis atopik. Intisari Sains Medis 12(2): 718-722. D0I: 10.15562/ism.v12i2.994

\section{ABSTRAK}

Dermatitis atopik (DA) merupakan penyakit multifaktorial yang diakibatkan disregulasi imun, suseptibilitas genetik, faktorlingkungan, dan gangguan fungsi barier. Beban kesehatan yang diakibatkan penyakit ini bersifat signifikan dan dapat berdampak pada kerugian psikologis, sosial, dan finansial, disertai komorbiditas sistemik. Terdapat beberapa studi yang telah melaporkan mikrobiota usus pada pasien DA. Mikrobiota usus diduga memainkan peran penting

dalam perkembangan DA dengan meregulasi maturasi sistem imun. Alterasi mikrobiota usus mempengaruhi keseimbangan sistem imun melalui produksi metabolit, yang akan menyebabkan lingkungan mikro mengalami inflamasi. Saat ini hubungan erat antara mikrobiota usus dan perkembangan sistem imun, khususnya dalam menjaga keseimbangan respon Th-1 dan Th-2 menjadi dasar pemikiran pemberian suplemen probiotik untuk mencegah atau mengatasi penyakit alergi dan atopi.

Kata kunci: dermatitis atopik, mikrobiota usus, probiotik.

Sitasi Artikel ini: Gotama, D., Wardhana, M., Santoso, A., Sissy. 2021. Mikrobiota usus pada dermatitis atopik. Intisari Sains Medis 12(2): 718-722. D0I: 10.15562/ism.v12i2.994

\section{PENDAHULUAN}

Dermatitis atopik (DA) merupakan penyakit kulit inflamasi bersifat kronis dan residif yang menyebabkan masalah kesehatan yang signifikan di dunia. Dermatitis atopik mengenai hingga $20 \%$ anak dan 3\% dewasa. Prevalensi ini ditemukan semakin meningkat, terutama di negara-negara berpenghasilan menengah ke bawah. ${ }^{1}$ Total prevalensi DA di dunia mencapai 230 juta orang. ${ }^{2}$ Asia Pasifik memiliki prevalensi yang lebih rendah dibandingkan prevalensi dunia, dengan prevalensi berkisar $10,1 \%$ pada anak berusia 6-7 tahun, dan $12 \%$ anak yang mengalami DA yang parah. ${ }^{2}$ Indonesia memiliki prevalensi yang lebih rendah dibandingkan rerata Asia, yaitu $<5 \%$, yang kemungkinan disebabkan oleh kurangnya pelaporan kasus tersebut. ${ }^{2}$ Distribusi lesi pada DA bergantung pada usia awitan dan beratnya penyakit. Morfologi DA sangat bervariasi dan bergantung pada stadium lesi. Sebagian besar kasus DA dapat menetap hingga usia dewasa.-5

Mikrobiota usus merupakan topik yang menimbulkan ketertarikan di dunia medis, karena ketidakseimbangan mikrobiota usus telah dihubungkan pada berbagai penyakit termasuk penyakit kulit seperti DA. Selain itu, strategi pencegahan dan pengobatan inovatif pada DA saat ini bertujuan untuk memanipulasi mikrobiota usus dengan probiotik, prebiotik maupun sinbiotik. ${ }^{3}$ Studi-studi menunjukkan bahwa pemberian probiotik dapat meringankan manifestasi klinis DA. ${ }^{4}$ Bukti-bukti klinis yang membahas korelasi mikrobiota usus dengan dermatitis atopik mulai bermunculan pada beberapa tahun terakhir, dan belum ada suatu tinjauan 
pustaka sistematis terbaru di Indonesia yang merampungkan berbagai bukti ini dalam tiga tahun terakhir.

Pada tinjauan pustaka ini akan membahas tentang mikrobiota usus pada kondisi dermatitis atopik untuk meningkatkan pemahaman mengenai mikrobiota usus dan pengaruhnya terhadap etiopatogenesis dari dermatitis atopik termasuk manfaat dari modulasi mikrobiota usus dengan probiotik, prebiotik dan sinbiotik sebagai alternatif atau terapi adjuvan pada dermatitis atopik.

\section{MIKROBIOTA USUS MANUSIA}

Istilah mikrobiota usus manusia merujuk pada keberagaman komunitas organisme mikrobial yang umumnya menghuni usus besar. ${ }^{5}$ Terdapat lebih dari 100 triliun bakteri yang berada pada saluran cerna manusia, dengan total spesies sebanyak seribu jenis. ${ }^{4}$ Mikrobiota yang tinggal pada mukosa manusia dapat dibedakan berdasarkan perilakunya yang menguntungkan atau merugikan hospesnya, stabilitasnya seiring waktu, dan predileksi lokasi kolonisasinya pada tubuh. Hubungan yang menguntungkan disebut mutualisme atau komensalisme. Berbagai bagian tubuh manusia dapat menjadi habitat, dan di usus biasanya dihuni bakteri anaerobik. Ekosistem usus manusia yang kompleks memungkinkan interaksi hospes dan mikroba. ${ }^{5}$

Sebagian besar organisme yang ditemukan dalam mikrobiota usus merupakan Firmicutes dan Bacteroidetes. Densitas populasi bakteri dalam usus bergantung pada lokasi anatomisnya. Contohnya, densitasnya adalah $10^{2-3}$ colony forming units (CFU) per gram di ileum proksimal dan jejenum, dibandingkan pada kolon asendens yang berkisar $10^{5-6}$ CFU per gram. Setiap individu yang sehat memiliki komunitas mikrobiota usus yang bisa sangat berbeda. Mikrobiota usus relatif stabil, namun studi-studi menunjukkan bahwa terapi antibiotik dan penyakit dapat merubah mikrobiota usus normal. Penuaan menyebabkan pergeseran spesies predominan dalam usus. Pola makanan jangka panjang juga berpengaruh terhadap mikrobiota usus. ${ }^{4}$

\section{Mikrobiota Usus Normal}

Jumlah sel-sel bakteri di dalam usus manusia berjumlah sepuluh kali lipat lebih banyak dibandingkan sel-sel usus hospes sendiri. Berbagai studi telah dilakukan mengenai mikrobiota usus manusia dan perannya dalam kesehatan maupun penyakit, yang menunjukkan interaksinya dengan nutrisi, metabolisme, fisiologi, dan fungsi imun. ${ }^{6}$

Usus bayi mengalami kolonisasi segera setelah bayi tersebut dilahirkan, melalui transmisi bakteri dari ibunya melalui barier plasenta. Cara persalinan juga mempengaruhi mikrobiota usus bayi. Persalinan dengan seksio cesarea mengurangi kolonisasi Bacteroides namun meningkatkan kolonisasi Clostridiae. ${ }^{6}$ Beberapa bakteri yang banyak ditemukan pada usus bayi yang dilahirkan secara seksio cesarea adalah Streptococcus, Staphylococcus, dan C. difficile. Spesies Bifidobacterium dan Bacteroides tertentu memainkan peran menekan respons inflamasi pada bayi, yang bermanfaat untuk kesehatannya. Bayi-bayi yang disusui dengan botol dominan koloni Escherichia coli dan Clostridium, sedangkan yang disusui ASI mengalami kolonisasi Bifidobacterium spesifik. Perkenalan makanan padat pada bayi menyebabkan pergeseran yang dinamis dari dominan Bifidobacterium menjadi dominan Bacteroides dan Clostridium. Mikrobiota ini akan tetap berada pada usus bayi hingga masa dewasa jika tidak mengalami masalah kesehatan yang serius, perubahan pola makan, atau penggunaan antibiotik jangka panjang. ${ }^{7}$

Jumlah mikroba dan keberagaman spesiesnya terus berkembang, dan masih tetap bersifat dinamis selama tiga tahun pertama kehidupan, dan setelah itu menjadi relatif stabil. ${ }^{8}$ Mikrobiota usus dapat diturunkan yang ditunjukkan oleh studi sekuens metagenomics shotgun pada orang dewasa yang kembar. Hal ini berbeda dengan mikrobiota kulit, yang sangat dipengaruhi oleh lingkungan.,9 Mikrobiota usus berperan penting terhadap perkembangan imunitas yang baik, terutama diferensiasi sel B dan T, sehingga penting untuk respons antibodi protektif. $^{6}$

\section{Mikrobiota Usus pada Dermatitis Atopik}

Terdapat beberapa studi yang telah melaporkan mikrobiota usus pada pasien DA. Studi oleh Watanabe dkk menemukan bahwa jumlah Bifidobacterium pada pasien DA lebih rendah dibandingkan individu sehat. Selain itu, jumlah dan persentase Bifidobacterium bergantung pada kondisi penyakit. Jumlah yang lebih rendah ditemukan pada DA berat, namun pasien dengan gejala atopik yang lebih ringan memiliki jumlah Bifidobacterium yang lebih banyak. Staphylococcus juga lebih banyak ditemukan pada pasien DA dibandingkan individu yang sehat. ${ }^{6}$

Studi pada bayi dengan DA yang dilakukan oleh Nylund dkk, dengan menggunakan analisis microarray pada mikrobiota usus bayi usia 6 dan 18 bulan, melaporkan bahwa tidak didapatkan perbedaan mikrobiota yang signifikan pada bayi usia 6 bulan, namun pada usia 18 bulan, bayi sehat memiliki jumlah Bacteroidetes yang tiga kali lipat lebih banyak sedangkan bayi dengan DA memiliki jumlah Clostridiae yang lebih

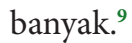

Studi lain yang dilakukan oleh Reddel dkk terhadap populasi mikrobiota usus anak-anak dengan DA menemukan bahwa kelompok anak-anak dengan DA mengalami kolonisasi bakteri Sutterella (Alcaligenaceae), Bacteroides (Bacteroidaceae), Parabacteroides (Porphyromonadaceae), Oscillospira dan Faecalibacterium (Ruminococcaceae, Clostridia Class), serta jumlah Eggerthella (Coriobacteriaceae), Propionibacterium (Propionibacteriaceae), Enterococcus (Enterococcaceae), Eubacterium (Erysipelotrichaceae), Actinomyces (Actinomycetaceae), Blautia dan Coprococcus (Lachnospiraceae) yang juga cukup banyak. Beberapa populasi bakteri umum seperti Staphylococcus (Staphylococcaceae), Bifidobacterium (Bifidobacteriaceae), Corynebacterium (Corynebacteriaceae), Bulleidia (Erysipelotrichaceae tidak ditemukan sama sekali. Studi ini menekankan kondisi disbiosis mikrobiota usus memang terjadi sebelum awitan dermatitis atopik, namun hingga saat ini, topik penyakit atopik dan mikrobiota masih perlu dipelajari lebih lanjut. ${ }^{10}$ 


\section{Hubungan Disbiosis Mikrobiota Usus dengan Dermatitis Atopik}

Mikrobiota usus diduga memainkan peran penting dalam perkembangan DA dengan meregulasi maturasi sistem imun. Alterasi mikrobiota usus mempengaruhi keseimbangan sistem imun melalui produksi metabolit, yang akan menyebabkan lingkungan mikro mengalami inflamasi. Disbiosis mikrobiota usus yang dikombinasikan dengan imbalans sistem imun dapat bertahan hingga masa dewasa, sehingga berkontribusi terhadap perjalanan alamiah penyakit, seperti DA. ${ }^{11}$

Berdasarkan studi, pembentukan mikrobiota usus pada masa bayi sangat berkaitan erat dengan perkembangan sistem imun. Studi-studi sebelumnya menemukan bahwa mikrobiota usus pada awal kehidupan berkaitan dengan usia awitan, keparahan, remisi, flare DA. ${ }^{6,11}$ Transformasi dari sel $\mathrm{T}$ naif menjadi beberapa tipe sel Th seperti Thl, Th2, dan Th17 atau Treg sebagian besar tergantung dari mikrobiota usus. Sel Treg dapat mencegah sel $\mathrm{T}$ naif berdiferensiasi menjadi sel Th dan mengontrol inflamasi dengan menurunkan regulasi aktivasi sel oleh sel mast, eosinofil, dan basofil. Treg juga menekan produksi dari IgE. Bifidobacterium, Lactobacillus, Clostridium, Bacteroides, Streptococcus dan produk metabolitnya berupa asam propionat dan asam butirat telah diketahui memiliki kemampuan dalam menginduksi sel Treg. ${ }^{6}$

Studi di Korea oleh Song dkk dan Kim dkk, melaporkan adanya temuan disbiosis yang signifikan dari spesies Faecalibacterium prausnitzii pada hasil pemeriksaan fekal pasien DA. Bersamaan dengan temuan tersebut juga didapatkan penurunan dari asam lemak rantai pendek (short chain fatty acid/SCFA). Asam lemak rantai pendek diketahui berperan dalam menjaga integritas dari barrier epithelial dan memiliki efek anti inflamasi. Kondisi pada pasien DA tersebut menyebabkan mudahnya penetrasi dari toksin dan mikroba masuk ke sirkulasi sistemik, dan ketika telah mencapai kulit, respon Th2 akan meningkat dan menyebabkan kerusakan jaringan. ${ }^{6,12}$

Terdapat bukti klinis yang menunjukkan hubungan antara disbiosis mikrobiota usus dan kondisi dermatologi, namun mekanismenya belum diketahui pasti. Beberapa studi yang ada juga mendukung adanya aksis usus dan kulit yang dimediasi molekul neuroendokrin yang diproduksi mikrobiota usus. Aksis ini telah didokumentasikan oleh Arck dkk, Bowe dan Logan. Stres psikososial telah diketahui berimplikasi terhadap eksaserbasi dan inisiasi berbagai kondisi kulit termasuk DA. Mikrobiota usus memproduksi neurotransmiter sebagai respons stres dan stimuli eksternal lainnya yang dapat memodulasi fungsi kulit melalui jalur neural. Contohnya, organisme komensal di usus dapat memproduksi norepinefrin, serotonin, dan asetilkolin atau dapat menyebabkan pelepasan neuropeptida dari sel-sel enteroendokrin terdekat. Berbagai neurotransmiter ini dapat menyeberangi epitel usus menuju aliran darah dan menginduksi efek-efek sistemik. Bersamaan dengan neurotransmiter, mikrobiota usus juga melepaskan SCFA, seperti asam propionat, asam butirat, asam asetat, dan asam laktat akibat fermentasi polisakarida dari makanan yang kita konsumsi. ${ }^{4}$

\section{Modulasi Mikrobiota Usus untuk Tatalaksana Dermatitis Atopik Probiotik}

MenurutFoodandAgricultureOrganization dari Perserikatan Bangsa-bangsa (PBB) dan World Health Organization, probiotik adalah mikroorganisme hidup, yang jika diberikan dalam jumlah yang cukup, memberikan manfaat kesehatan yang baik pada hospesnya. Hal ini dicapai dengan membantu keseimbangan mikrobiota usus yang baik. ${ }^{13}$

Probiotik memodulasi respons imun humoral (meningkatkan IgA dan mengurangi IgE), menyeimbangkan respons imun dimediasi sel (meningkatkan sel Treg dan mengurangi respons Th2), berkompetisi dengan bakteri patogen, dan memodifikasi microenvironment. ${ }^{6}$ Secara lengkap, probiotik mengurangi keparahan DA dengan menginhibisi respons yang dimediasi Th2, sitokin seperti IL-4, IL5, IL-6, dan IL-13, IFN-gamma, serta stimulasi fagositosis. Probiotik juga menginduksi sekresi IL-10 dan TGF-beta, dan mengurangi sitokin pro-inflamasi seperti IL-4, IL-6, tumor necrosis factor alpha (TNF-alfa), IFN-gamma, dan high sensitivity $\mathrm{C}$ reactive protein (hsCRP) dan meningkatkan ekspresi IL-10 dan sitokin terkait Treg di nodus-nodus limfe mesenterika. ${ }^{14}$

Hubungan erat antara mikrobiota usus dan perkembangan sistem imun, khususnya dalam menjaga keseimbangan respon Th-1 dan Th-2 menjadi dasar pemikiran pemberian suplemen probiotik untuk mencegah atau mengatasi penyakit alergi dan atopi. ${ }^{15}$ Suplementasi probiotik dapat diberikan dalam bentuk kapsul, bubuk, minuman atau makanan. Dua bakteri yang paling sering diberikan sebagai probiotik adalah Lactobacillus dan Bifidobacterium. ${ }^{4}$

Studi yang dilakukan oleh Kim dkk di Korea terhadap mencit-mencit dengan memberikan intervensi Lactobacillus fermentum KBL375 pada mencit dengan DA didapatkan hasil yang signifikan dalam mengurangi skor dermatitis dan kadar IgE serum yang diinduksi dermatitis atopik tersebut. ${ }^{16}$

Studi lain dengan mencit yang dilakukan oleh Yeom dkk, ditemukan bahwa DA pada mencit membaik dengan pemberian oral Lactobacillus casei var. rhamnosus (LCR35), yang meningkatkan populasi Bacteroides fragilis, Lactobacilli, Bifidobacterium dan Enterococcus pada usus, serta menurunkan populasi Clostridium coccoides. Intervensi ini juga memperbaiki balans Th1/Th2. ${ }^{17}$

Studi acak prospektif yang dilakukan Iemoli dkk, mengujikan pemberian Lactobacillus salivarius LS01 dan Bifidobacterium breve BR03 oral selama 12 minggu pada para pasien dengan DA, menemukan perbaikan keparahan DA (yang dinilai dengan indeks SCORAD), kualitas hidup (dermatology quality of life index), dan rasio Th17 terhadap Treg, serta penurunan aktivasi sistem imunitas dan translokasi mikroba. ${ }^{18}$

Studi pemberian probiotik dengan desain randomized controlled trial prospektif pada pasien DA dewasa dilakukan oleh Matsumoto dkk, ditemukan bahwa pemberian probiotik Bifidobacterium animalis subsp lactis (LKM512) secara oral meringankan gejala pruritus pada pasien dengan DA. Analisis metabolomik menemukan bahwa efek antipruritus yang dihasilkan disebabkan 
Tabel 1. Spesies bakteri probiotik yang digunakan pada DA. ${ }^{14}$

\begin{tabular}{ccc}
\hline Lactobacillus & Bifidobacterium & Saccharomyces \\
\hline L. rhamnosus GG & B. longum reuter & Saccharomyces boulardii \\
L. rhamnosus LC705 & B. longum infantis & \\
L. fermentum VRI-033 & B. breve & \\
L. paracasei & B. lactis UABLA-12 & \\
L. plantarum & & \\
L. salivarius & & \\
L. acidophilus & & \\
\hline
\end{tabular}

oleh peningkatan produksi asam kinurenat pada feses. ${ }^{19}$

Uji probiotik dengan desain open trial dilakukan terhadap 130 perempuan hamil, yang diberikan $B$. breve $\mathrm{M} 16 \mathrm{~V}$ dan Bifidobacterium longum BB536 satu bulan sebelum melahirkan. Sebanyak 36 pasang ibu dan bayi ditempatkan sebagai kontrol. Setelah kelahiran bayi, para bayi tersebut diberikan kombinasi probiotik yang sama selama enam bulan. Risiko DA ditemukan berkurang secara bermakna pada 18 bulan pertama kehidupan (OR: 0,304). Perubahan sementara pada mikrobiota usus ditemukan pada bayibayi yang mengalami DA. ${ }^{20}$ Jenis bakteri yang digunakan sebagai probiotik pada DA dapat dilihat pada Tabel 1.

\section{Prebiotik}

Prebiotik adalah komponen makanan yang tidak dapat dicerna yang menguntungkan hospes dengan secara selektif menstimulasi pertumbuhan dan aktivitas mikroorganisme. Prebiotik seringkali didapat dalam bentuk oligosakarida. Serat makanan dan inulin dapat ditemukan pada sayuran tertentu dapat dikatakan sebagai prebiotik. ${ }^{3} \quad$ Studi-studi menunjukkan bahwa serat dan oligosakarida dapat memperbaiki imunitas dan metabolisme, dan bahwa pemberian kedua komponen tersebut pada tikus yang hamil dan menyusui meningkatkan proporsi Lactobacillus dan Clostridium leptum, serta mempromosikan efek protektif jangka panjang terhadap asam lemak pada anak-anaknya. ${ }^{15}$ Prebiotik berperan penting sebagai makanan bagi para bakteri komensal dan bagi probiotik, sehingga berperan penting untuk mikrobiota usus. ${ }^{6}$

Studi acak kontrol pertama yang dilakukan pada bayi dengan risiko tinggi DA menginklusikan 259 pasien yang masih berusia 0-6 bulan. Para bayi dibagi menjadi dua kelompok, yaitu kelompok yang mendapat kombinasi prebiotik galakto-oligosakarida dan frukto-oligosakarida rantai panjang, dan kelompok plasebo. Pada akhir studi, didapatkan 9,8\% bayi pada kelompok yang mendapat kombinasi prebiotik mengalami DA dan 23,1\% pada kelompok plasebo mengalami DA. Hasil ini menunjukkan efek yang lebih baik pada kelompok yang diberikan prebiotik. $^{21}$ Studi lain oleh Harima-Mizsawa dkk memberikan jus sitrus fermentasi Lactobacillus plantarum YIT 0132 (LP0132) pada para orang dewasa dengan DA. Hasil studi menemukan perbaikan gejala DA selama delapan minggu masa pengobatan, dan delapan minggu berikutnya setelah pengobatan berakhir. ${ }^{22}$

Hasil yang berbeda didapatkan oleh dua studi acak prospektif dengan kontrol plasebo yang dilakukan Bozensky dan Van der Aa, yang menginklusikan para bayi dan diberikan prebiotik galaktooligosakarida atau campuran probiotik. perbaikan atau pengurangan keparahan DA. ${ }^{23,24}$ Satu laporan lain pada para bayi dengan risiko tinggi mengusulkan adanya efek preventif sementara terhadap DA. ${ }^{25}$

\section{Sinbiotik}

Sinbiotik berasal darikata syn berarti sinergi dan biotic berarti hidup. Sinbiotik berarti potensi yang sinergi antara probiotik dan prebiotik..$^{15}$ Sebuah meta-analisis dari uji kontrol acak menemukan bahwa dengan pemberian sinbiotik (prebiotik ditambah probiotik dari beberapa galur mikroba yang berbeda) bagi anak-anak berusia di atas satu tahun, ditemukan efektivitas yang baik dalam pengurangan keparahan DA dan pencegahan DA. ${ }^{26}$ Pada penelitian, preparat sinbiotik dapat memberikan hasil yang lebih baik pada pencegahan dan terapi DA dibandingkan terapi tunggal

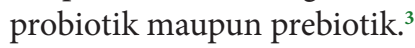
Kedua studi ini gagal mendapatkan

\section{SIMPULAN}

Terdapat bukti-bukti klinis yang menunjukkan hubungan antara disbiosis mikrobiota usus dan kondisi dermatologi, namun mekanismenya belum diketahui dengan jelas. Modulasi pada mikrobiota usus dapat dilakukan dengan pemberian probiotik, prebiotik atau sinbiotik. Bakteri yang paling sering diberikan sebagai probiotik adalah Lactobacillus dan Bifidobacterium. Probiotik diduga meringankan dermatitis atopik dengan meningkatkan diversitas flora usus, berkompetisi dengan bakteri patogen, menghambat respon yang dimediasi Th2 dan mengurangi sitokin proinflamasi. Prebiotik merupakan komponen makanan yang dapat menstimulasi pertumbuhan dan aktivitas mikroorganisme termasuk probiotik sedangkan sinbiotik memiliki potensi dari probiotik dan prebiotik sehingga berdasarkan studi, sinbiotik dilaporkan dapat memberikan hasil yang lebih baik pada pencegahan dan terapi DA dibandingkan terapi tunggal dengan probiotik maupun prebiotik.

\section{KONFLIK KEPENTINGAN}

Tidak ada konflik kepentingan terkait publikasi tinjauan pustaka ini.

\section{PENDANAAN}

Tidak ada.

\section{KONTRIBUSI PENULIS}

Seluruh penulis berkontribusi terhadap publikasi tinjauan pustaka ini.

\section{DAFTAR PUSTAKA}

1. Nutten S. Atopic dermatitis: Global epidemiology and risk factors. Ann Nutr Metab. 2015;66:8-16.

2. Tsai TF, Rajagopalan M, Chu CY, Encarnacion L, Gerber RA, Santos-Estrella P, et al. Burden of atopic dermatitis in Asia. J Dermatol. 2019;46(10):825-34.

3. Van Der Aa LB, Heymans HSA, Van Aalderen WMC, Sprikkelman AB. Probiotics and prebiotics in atopic dermatitis: Review of the theoretical background and clinical evidence. Pediatr Allergy Immunol. 2010;21:355-67.

4. Vaughn AR, Notay M, Clark AK, Sivamani RK. Skin-gut axis: The relationship between intestinal bacteria and skin health. World J Dermatology. 2017;6(4):52-8.

5. Wardhana M, Suryawati N, Rusyati LMM. The role of psychological stress in atopic dermatitis 
through an increase of il-31. Bali Med J. 2020;9(1):27-30.

6. Pothmann A, Illing T, Wiegand C, Hartmann AA, Elsner P. The Microbiome and Atopic Dermatitis: A Review. Am J Clin Dermatol. 2019;20(6):749-61.

7. Kim J, Kim H. Microbiome of the Skin and Gut in Atopic Dermatitis (AD): Understanding the Pathophysiology and Finding Novel Management Strategies. J Clin Med. 2019;8(4):444.

8. Wollina U. Microbiome in atopic dermatitis. Clin Cosmet Investig Dermatol. 2017;51-6.

9. Yassour M, Vatanen T, Siljander H, Hämäläinen A, Hamalainen A, Al E. Natural history of the infant gut microbiome and impact of antibiotic treatments on strain-level diversity and stability. Sci Trans Med. 2016;8(343):1173-8.

10. Nylund L, Satokari R, Nikkilä J, RajilićStojanović M, Kalliomäki M, Isolauri E, et al. Microarray analysis reveals marked intestinal microbiota aberrancy in infants having eczema compared to healthy children in at-risk for atopic disease. BMC Microbiol. 2013;13(12):111.

11. Reddel S, Del Chierico F, Quagliariello A, Giancristoforo S, Vernocchi P, Russo A, et al. Gut microbiota profile in children affected by atopic dermatitis and evaluation of intestinal persistence of a probiotic mixture. Sci Rep. 2019;9(1):1-10.

12. Lee SY, Lee E, Park YM, Hong SJ. Microbiome in the gut-skin axis in atopic dermatitis. Allergy, Asthma Immunol Res. 2018;10(4):354-62.

13. Song $\mathrm{H}$, Yoo Y, Hwang J, Na YC, Kim HS. Faecalibacterium prausnitzii subspecieslevel dysbiosis in the human gut microbiome underlying atopic dermatitis. J Allergy Clin Immunol. 2016;137(3):852-60.
14. Pascal M, Perez-Gordo M, Caballero T, Escribese MM, Lopez Longo MN, Luengo O, et al. Microbiome and allergic diseases. Front Immunol. 2018;9(1584):1-9.

15. Rusu E, Enache G, Cursaru R, Alexescu A, Radu R, Onila O, et al. Prebiotics and probiotics in atopic dermatitis (Review). Exp Ther Med. 2019;18:926-31.

16. Vael C, Desager K. The importance of the development of the intestinal microbiota in infancy. Curr Opin Pediatr. 2009;21(6):794800.

17. Kim WK, Jang YJ, Han DH, Seo B, Park S, Lee $\mathrm{CH}$, et al. Administration of lactobacillus fermentum KBL375 causes taxonomic and functional changes in gut microbiota leading to improvement of atopic dermatitis. Front $\mathrm{Mol}$ Biosci. 2019;6(92):1-12.

18. Yeom M, Sur BJ, Park J, Cho SG, Lee B, Kim ST, et al. Oral administration of Lactobacillus casei variety rhamnosus partially alleviates TMAinduced atopic dermatitis in mice through improving intestinal microbiota. J Appl Microbiol. 2015;119(2):560-70.

19. Iemoli E, Trabattoni D, Parisotto S, Borgonovo L, Toscano M, Rizzardini G, et al. Probiotics reduce gut microbial translocation and improve adult atopic dermatitis. J Clin Gastroenterol. 2014;46(Supp.1):S33-40.

20. Matsumoto M, Ebata T, Hirooka J, Hosoya R, Inoue $\mathrm{N}$, Itami $\mathrm{S}$, et al. Antipruritic effects of the probiotic strain LKM512 in adults with atopic dermatitis. Ann Allergy, Asthma Immunol. 2014;113(2):209-16.

21. Enomoto T, Sowa M, Nishimori K, Shimazu $S$, Yoshida A, Yamada K, et al. Effects of bifidobacterial supplementation to pregnant women and infants in the prevention of allergy development in infants and on fecal microbiota. Allergol Int. 2014;63(4):575-85.

22. Moro G, Arslanoglu S, Stahl B, Jelinek J, Wahn U, Boehm G. A mixture of prebiotic oligosaccharides reduces the incidence of atopic dermatitis during the first six months of age. Arch Dis Child. 2006;91(10):814-9.

23. Harima-Mizusawa N, Kamachi K, Kano M, Nozaki D, Uetake T, Yokomizo Y, et al. Beneficial effects of citrus juice fermented with Lactobacillus plantarum YIT 0132 on atopic dermatitis: Results of daily intake by adult patients in two open trials. Biosci Microbiota, Food Heal. 2015;35(1):29-39.

24. Boženský J, Hill $M$, Zelenka R, Skýba T. Prebiotics do not influence the severity of atopic dermatitis in infants: A randomised controlled trial. PLoS One. 2015;10(11):1-8.

25. Chang Y Sen, Trivedi MK, Jha A, Lin YF, Dimaano L, García-Romero MT. Synbiotics for prevention and treatment of atopic dermatitis: A meta-analysis of randomized clinical trials. JAMA Pediatr. 2016;170(3):236-42.

26. Grüber C, Van Stuivenberg M, Mosca F, Moro G, Chirico G, Braegger CP, et al. Immunoactive prebiotics transiently prevent occurrence of early atopic dermatitis among low-atopy-risk infants. J Allergy Clin Immunol. 2015;136(6):14.

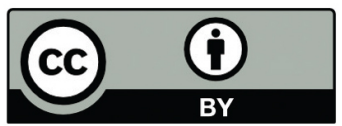

This work is licensed under a Creative Commons Attribution 